\title{
Evolution of Handloom Weaving Activity in India
}

\author{
Saddam Faruque ${ }^{1}$ and Bodrul Islam ${ }^{1}$ \\ ${ }^{I}$ Research Scholar, Department of Economics, Sikkim University, Gangtok, Sikkim \\ Email: sfaruque@ sikkimuniversity.ac.in and bodrulalam42@gmail.com
}

\begin{abstract}
This paper seeks to place the evolution of handloom weaving activity and its current scenario in Indian economy. Though the handloom weaving of India had a glorious past, the colonial regime shattered the hand spinning culture of traditional handloom sector of India and forced the country as the supplier of raw materials to Britain. Factory-made cheap cloths had replaced the Indian handwoven fabrics within the country, and weavers lost their employment due to the shutdown of handloom units. Despite such adversity of handloom sector, Indian artisans had stood the test of time and had kept this great craft alive. The phasing out of the MFA has placed India in an advantageous position in international market for handloom.
\end{abstract}

Keywords: handloom, evolution, decline, revival, trade, India

\section{Introduction}

The handloom weaving is one of the most important economic activities in India in terms of providing non-farm employment to backward and down trodden people, contributing in country's export earnings, and preserving the culture and heritage of the country. From its past glory the handloom weaving can be termed as a time honored artisans' activity; no other country in the world has preserved and upheld this ancient craft in such pure form as India does. The age old handloom weaving activity in India has passed through several historical, political, and economic developments. This paper seeks to explore the evolution and development of handloom weaving activity in India, which are discussed in subsequent sections.

\section{Handloom Weaving in early Days}

The art of weaving is an age old tradition in India since time immemorial with the earliest evidences traced back to the Indus Valley civilization. Spinning and weaving were highly advanced occupations in rig vedic society in which weavers were engaged in weaving cotton and woolen fabrics while others were engaged in dyeing and embroidering. Until the beginning of industrial revolution in Europe, India was an exporter of textile products especially muslin and silk cloth. With Vasco-DaGama's discovery of trade route between India and Europe in 1498, countries like Portugal, Spain, Holland, France and Britain took interest in setting up trading companies in India with a view to purchase textile products from India. From the sixteenth century European trading companies began buying Indian textiles for sale in Europe and by the end of the seventeenth century, 83 per cent of the East India Company's trade accounted for the export of clothing (Ministry of Textile, 2019). Till the end of the eightieth century, Indian handloom sector was the sole supplier of cloths; however such monopoly came to an end by the early ninetieth century due to the industrial revolution in Europe.

\section{Decline of Handloom Weaving}

With the advent of the industrial revolution in Europe and immediately followed by the invention of spinning jenny in England, hand spinning which provided occupation to a large number of Indian people was completely replaced by the increased use of mill yarn. The colonial regime shattered the hand spinning culture of traditional handloom sector of India and forced the country as the supplier of raw materials to Britain. British began executing a protectionist policy in order to restrict the import 
of hand-woven fabric from India to Britain while dumping their machine-made clothes in India from Lancashire. The recessionary trend in Indian textile sector began with the development of cotton industries in Britain and by the end of the ninetieth century, English-made cotton textiles successfully ousted Indian textiles from their traditional markets in Africa, America and Europe. The Indian handloom weaving sector started facing competition from indigenous textile mills too with the establishment of the first textile mill in Bombay in 1851. Factory-made cheap cloths had replaced the Indian hand-woven fabrics within the country, and weavers lost their employment due to the shutdown of handloom units.

\section{Revival of Handloom Weaving}

Despite adversity of handloom sector, Indian artisans had stood the test of time and had kept this great craft alive. Indeed, for the period ranging end of the nineteenth century and the first three decades of the twentieth century, there was an enduring brawl between the dumping of British mill products versus Indian hand-woven cloths with the rising call of Swadeshi goods. Swadeshi movement of boycotting British products was popularized by Mahatma Gandhi and Indian mill owners, backed nationalist politicians, who called for a boycott of foreign cloths. Mahatma Gandhi started spinning himself and encouraged Indians to turn to handicrafts in order to become self-sufficient and boycott British imports. Gandhi made it obligatory for all members of the Indian National Congress to spin cotton themselves and collected large sums of money to create a grass-roots organization to encourage handloom weaving. India's independence from British rule marked a turning point for the handloom weavers of India which was largely attributed to Mahatma Gandhi's use of charkha, the spinning wheel, as a symbol of national regeneration and the subsequent focus on the handloom weavers during the freedom movement.

\section{Handloom Weaving in Post Independence Era}

In the post-independence era, a number of institutions were established in different five-year plans period to channelise financial resources and other managerial assistance to the handloom sector. Also, to look into the difficulties of weavers and the sector, different committees were appointed at different times. With a view to assist the handloom sector, the government of India had established Cottage Industries Board in 1948 with a standing committee to look after the interests of the handloom weavers, and a handloom development fund of Rs.10 lakhs was also placed at the disposal of the committee. During the same year, the then Chief Minister of the composite Madras state C. Rajagopalachary formed a reservation policy for handloom products, and thus the notification of cotton control order 1948 under section 3 of the Essential Commodities Act was issued; by which Act certain items of clothes like sari and dhoties were legally prohibited from producing by mills and these items were exclusively reserved for handlooms with effect from June 1, 1950. In 1953 Government of India adopted Khadi and other handloom industries (Additional Excise Duty on Mill Cloth) Act 1953, which provided duty on mill cloths with a view to enhance, assist and develop the handloom industry in terms of production, marketing, and quality control. For export promotion efforts of handloom fabric, Government of India constituted the Handloom Export Promotion Council in 1965 as a nodal agency for export promotion. Two important schemes viz. Intensive Development of Handlooms and Export Oriented Projects were started in 1976 by the Government of India in response to the suggestion by high powered committee on handlooms. In 1984, the Association of Corporations and Apex Societies of Handloom (ACASH) was set up to promote marketing in the handloom sector of the country, which acted as a nodal agency for the supply of handloom products to be purchased by various departments and agencies of the Government of India. During the fifth plan period, priority had been given for the development of handloom through the 20 point economic program. Handloom (Reservation of Articles for Production) Act 1985, reserving 22 items of clothing for exclusive production in the handloom sector was a major concrete initiative in the direction of protecting handlooms from the power loom and mill sectors. The Abid Hussain committee was appointed in 1990 to review the textile policy of 1985 which mainly focused on weavers. With a view to provide all types of yarn at Mill gate price to the organization of weavers, Mill Gate Price Scheme was introduced in 1992-93. 


\section{International Trade and Current Scenario}

International trade in textiles and clothing had, so far, been governed by a separate set of Agreements, under which developed countries imposed discriminatory quotas on exports of textiles and apparel from developing countries, violating the GATT's principle of non-discriminatory treatment, with a view to protect the domestic markets. The separate set began with a Short Term Agreement (STA) in 1961 for international trade in cotton textiles. It was soon converted into a Long Term Agreement (LTA) negotiated in 1962 for five years which was twice renewed for terms of three years ending in 1973. It is worth noting that despite these initiatives taken by the developed countries, the 12-year term of LTA witnessed growth in exports of textile products from less developed countries particularly due to changing trends in consumer preferences for non-cotton fibres. As a result, the developed countries tried to bring imports of non-cotton textile products under control and such effort was finally succeeded with the signing of Multi-fibre Agreement (MFA) in 1974, which extended the coverage of discriminatory quotas from cotton textiles to wool and manmade fibres. The MFA was renegotiated four times, the last time in 1991, and it finally expired in 1994. During MFA regime countries which are rich in textiles production such as China, India, Korea, etc. remained at a disadvantageous position and witnessed a negative pinch as their production and exporting capacity always remained in excess of the quotas (Chaudhary, 2011). For gradual dismantling of quotas, MFA was followed by the Agreement on Textiles and Clothing (ATC), which came into force with the establishment of the World Trade Organization (WTO) in 1995. ATC was a transitional agreement that regulated trade in textiles for 10 years after which with the elimination of all remaining textile quotas from January 1, 2005, the textile and clothing sector was fully integrated into the regulatory framework of the General Agreement on Tariffs and Trade (GATT) of the World Trade Organization (WTO). The completion of phasing out of the MFA on 1st January 2005 would expand the size of the market available to the major textiles producing countries that had been restricted by the quotas. India has placed in an advantageous position to exploit the larger market available in the post-MFA regime. During the post-quota period, India has emerged as a major sourcing destination for new buyers. India's textiles and clothing export recorded robust growth of 25 per cent in 2005-06, and the growth continued in 2006-07 recording an increase of 9.28 per cent over the previous year (Chaudhary, 2011). After the MFA phase-out, India's cotton textiles including handlooms exports grew from US\$ 4600.78 million in 2005-06 to US\$ 5564.15 million in 2006-07 (Chaudhary, 2011). During 2007-08 the cotton textiles exports of the country amounted to US\$ 6851 million, recording a healthy growth of 23.14 per cent over the exports during previous year (Chaudhary, 2011). Total Textile and clothing exports of India were valued at US\$ 39.2 billion in 2015-16, which increased to US\$ 40.4 billion in 2018-19 (Ministry of Textile, 2019). India became the world's second largest exporter of handloom cloths, with exports valued at US\$ 353.9 million in 2017-18 (EXIM Bank of India, 2018). As per EXIM bank of India report of 2018, the major export markets of Indian handloom products include USA, UK, Spain, Italy, Germany, UAE, France, Netherland, Australia, and Japan.

\section{Marketing of Handloom Fabrics}

Handloom weaving activities in India mostly being carried out on an informal basis, the marketing of handloom fabrics is performed by various agents viz. weavers themselves, master weavers, middlemen, co-operative societies. Within the institutional, there are some national organizations directly or indirectly supporting and promoting the marketing facilities of handloom cloths for both domestic and export purposes, notably the Association of Corporations \& Apex Societies of Handlooms, National Handloom Development Corporation, and Handloom Export Promotion Council. These agencies are expected to protect the interest of handloom weavers by releasing them from the clutches of middlemen and providing sufficient facilities for marketing their products at competitive prices. For proper marketing and export across countries, they provide financial aid. During the financial year 2016-17, an amount of INR 40.96 crore was released as marketing incentives by the government of India (EXIM Bank of India, 2018). As per the information given by the Union Minister of Textiles, Smriti Zubin Irani, in Lok Sabha on $6^{\text {th }}$ December 2019, these marketing agencies have provided marketing opportunities to 6,78,500 weavers during last two years (Ministry of Textile, 2019). 


\section{Conclusion}

Until the beginning of industrial revolution in Europe, India was an exporter of textile products especially muslin and silk cloth. Till the end of the eightieth century, Indian handloom sector was the sole supplier of cloths; however such monopoly came to an end by the early ninetieth century due to the industrial revolution in Europe. India's independence from British rule marked a turning point for the handloom weavers of India which was largely attributed to Mahatma Gandhi's use of charkha, the spinning wheel, as a symbol of national regeneration and the subsequent focus on the handloom weavers during the freedom movement. In the post-independence era, the consistent supports and assistance of Indian government helped in surviving and developing the handloom sector of the country. The phasing out of the MFA on 1st January 2005 has placed India in an advantageous position to exploit the larger market available in the post-MFA regime. There has been a rapid increase in the exports of India's cotton textiles including handlooms after the MFA phase-out.

\section{References}

[1] Chaudhary, A. (2011). Changing Structure of Indian Textiles Industry after MFA (Multi Fiber Agreement) Phase out: A Global Perspective. Far East Journal of Psychology and Business, 2 (2), 1-23.

[2] Export-Import Bank of India. (2018). Indian Handloom Industry: Potential and Prospects. Working Paper No. 80, Mumbai, India.

[3] Harnetty, P. (1991). 'Deindustrialization' Revisited: The Handloom Weavers of the Central Provinces of India, c.1800-1947. Modern Asian Studies, 25(3), 455-510.

[4] Kar, M. (2012). National and Global Aspects of India's Textiles and Apparel Industry and Trade: An Overview. South Asian Journal of Macroeconomics and Public Finance, 1(1) 81-133.

[5] Ministry of Textile. (2019). Annual Report 2018-19. New Delhi: Government of India.

[6] National Council of Applied Economic Research. (2010). Third Handloom Census of India 2009-10. New Delhi: Ministry of Textile, Government of India.

[7] Niranjana, S. (2001). Appraising the Indian Handloom Industry. Economic and Political Weekly, 36(45), 42484250.

[8] Nordås, H.K. (2004). The Global Textile and Clothing Industry post the Agreement on Textiles and Clothing. World Trade Organization. Discussion Paper No 5.

[9] Souza, D. E. (2005) The WTO and the Politics of Reform in India's Textile Sector: From Inefficient Redistribution to Industrial Upgradation. Paper Prepared for the Research Project on 'Linking the WTO to the Poverty-Reduction Agenda'.

[10] Tewari, M. (2005). Post-MFA Adjustments in India's Textile and Apparel Industry: Emerging Issues and Trends. Working Paper No. 167. 